\title{
- Distribution and Occurrence of Four Caddisfly Species in Genus Macrostemum along Nan River in Nan Province, Thailand
}

\author{
Terdthai Phutthanurak and Decha Thapanya*
}

Department of Biology, Faculty of Science, Chiang Mai University, Chiang Mai 50200, Thailand

*Corresponding author. E-mail: Thapanya2@hotmail.com https://doi.org/10.12982/CMUJNS.2020.0063

\author{
Received: December 16, 2019 \\ Revised: April 16, 2020 \\ Accepted: April 20, 2020
}

\begin{abstract}
Database of Thai caddisfly still lacks a record of Nan River-one of four main rivers in northern Thailand. The pioneer study on four interesting species in genus Macrostemum (M. dohrni, M. floridum, M. indistinctum and M. midas: Hydropsychidae, Trichoptera) was done along Nan River in ChiangKlang and Tung-Chang Districts, Nan Province, Northern Thailand. Eight sampling sites were monthly set portable light traps for collecting adult caddisfly (both male and female) and recorded environmental factors and riverbed habitats for a year (November 2016 - October 2017). M. dohrni and $M$. indistinctum were rare in the study $(4 \%$ and $1 \%$ of all specimens, respectively), which their spatial distribution and temporal occurrence were showed. M. indistinctum abundance had the different seasonal pattern from other species that were mostly dominant in hot season. M. floridum was common (86\% of all specimens) and their male and female had significant negative relationship to the relative air humidity $(P<0.05)$. The life cycle of the studied species was univoltine. Although Nan River highly found river modification and agricultural activities, the nutrient concentrations were still low and habitats were available for other aquatic insects that suitable for further environmental and taxonomic studies.
\end{abstract}

Keywords: Biomonitoring, Trichoptera, Northern Thailand, Seasonal occurrence, Spatial and temporal distribution 


\section{INTRODUCTION}

Caddisflies or Trichoptera are the most diverse and abundant aquatic insects that inhabit in many natural freshwater resources like pond, lake, stream and river around the world (Anderson, 1976; Collier and Smith, 1995). Their larvae live in water and the adults emerge from water living on land for mating. Therefore, caddisflies play an important role in food web of both aquatic and terrestrial ecosystems as major primary consumer and food source of fish, birds and other terrestrial and aquatic animals (Wiggins, 1996). Caddisflies are also the key organism of litter decomposer as same as mayflies and stoneflies (Suhaila and Che Salmah, 2017). Those help to improve water quality. Because caddisflies are common in streams and rivers, they are normally selected for biomonitoring researches. The previous study in Thailand showed relationship between diversity of adult caddisflies and some environmental factors (e.g. air temperature, $\mathrm{pH}$ and turbidity) (Chaibu et al., 2002; Prommi et al., 2014), which it can be assumed that caddisfly might be an indicator for monitoring water pollution. The study in Netherland also mentioned some caddisflies species in family Glossomatidae that were found only at unimpacted stream (Nijboer, 2004), which it supports that caddisflies could be effective organism for water pollution assessment. Therefore, the information on caddisflies can help to develop water quality monitoring method by using these organisms as bioindicator (De Moor and Ivanov, 2008).

In 2009, caddisfly around the world belonged to 13,574 species (Morse, 2011). Thailand had 1,004 recorded species (7.4\% of global record) and many areas were still unexplored (Bunlue et al., 2012). Northern Thailand covers four main rivers: Ping, Wang, Yom and Nan Rivers that flow to the central Thailand and drain into Chao Phraya River - the major river of Thailand. But only Ping River has been studied on diversity of caddisfly (Chaibu et al., 2002) and caddisfly record of Nan River was absent.

Nan River is interesting to study adult caddisfly as the representative of disturbed area where is inhabited by tolerance caddisfly and highlights sensitive species. The river highly provides natural resources for local people and is important for agricultural utilization. A lot of water is pumped for plantation and livestock causing soil erosion. Riverbank has been continually modified for supporting farm management. Nan River had ever been reported as the deteriorated river because of the contaminated domestic waste (PCD, 2003). However, the artificial water channel of Nan River can introduce long-term effects on the living community and the loss of biodiversity. The development of agricultural and urban areas along the river is human disturbance on aquatic insect habitats that can affect diversity and abundance (Shafie et al., 2017). The disturbance on habitat causes the great impact on the aquatic insects like caddisflies. The previous study in the Mae Ngat Somboonchol Dam, Thailand, noted that the richness and abundance of the caddisflies were reduced by the 
change of stream characteristic through flooding and creating a new temporary lentic ecosystem (Promwong and Thapanya, 2019). Therefore, the record of caddisfly diversity in Nan River should be rapidly done. The study aimed to complete database of Thai caddisfly and develop rapid assessment of water quality. The initial survey on family Hydropsychidae that has widely distribution and high species richness in Thailand was focused, especially in genus Macrostemum that has available taxonomic identification for both male and female (Gordon and Wallace, 1975; Badcock, 1976; Prommi et al., 2014; Prommi, 2016; Ríos-Touma et al., 2017). Four Macrostemum species were investigated their distribution and occurrence along Nan River and analyzed the relationship with environmental characteristics and riverbed habitats to consider the possibility to apply for environmental monitoring. The study will be the first documentary of adult caddisfly in Nan River.

\section{MATERIAL AND METHODS}

\section{Sampling sites}

Nan River, the $5^{\text {th }}$ order stream, is the longest river in northern Thailand that flows through Nan, Uttaradit, Phitsanulok, Phichit and Nakhon-Sawan Provinces and drains into Chao Phraya River, the major River of Thailand. Adult caddisflies and environmental factors were collected at Nan River in the area of two districts ( 2 sampling sites: TC1 and TC2 in Thung-Chang District, and 6 sampling sites: CK1 - CK6 in Chiang-Klang District) (Figure 1). The sampling sites were surrounded by forest, agricultural and urban areas in 4 local villages (Ban Pa Pueai, Ban Don Sop Puea, Ban So Den Phatthana and Ban Tuet Villages). The first sampling site in Thung-Chang District was $66 \mathrm{~km}$ from headwater in Bo-Kluea District and the last sampling sites in Chiang-Klang District was 127 $\mathrm{km}$ from headwater. The sampling sites located at the altitude of $246-374 \mathrm{~m}$ above sea level (Table 1). The river was more than $10 \mathrm{~m}$ wide and less than $1 \mathrm{~m}$ deep during dry season (cool and hot seasons), whereas rainy season showed the depth of more than $2 \mathrm{~m}$. The riverbed substrates mostly were boulders and cobbles that were covered with green filamentous algae during the blooming period in cool season. Repetitive reconstruction of riverbank was usually found in agricultural and urban areas.

\section{Adult caddisfly collecting and identifying}

Portable black light trap (10w UV blacklight fluorescent tube connected to $12 \mathrm{~V}$ DC Battery on 12-inch plastic basin with diluted detergent solution) was used to collect adult caddisflies for 12 hours (6.00 PM to 6.00 AM) at each sampling site by placing at $2 \mathrm{~m}$ from river to avoid water-level increase during rainy season. Insect specimens were monthly collected for a year (November 2016 to October 2017) and preserved in 80\% Ethyl alcohol for sorting, identifying and counting under a stereo-microscope following the Atlas of Southeast Asian 
Trichoptera (Malicky, 2010). Basic morphology of male and female caddisflies was studied. For male caddisflies, the genitalia of each species are unique and were used for identification, whereas female in genus Macrostemum has specific wing patterns (Figure 2). The frequency of occurrence was analyzed to compare monthly abundance and the total number of caddisfly was indicated to show distribution pattern along eight sampling sites.

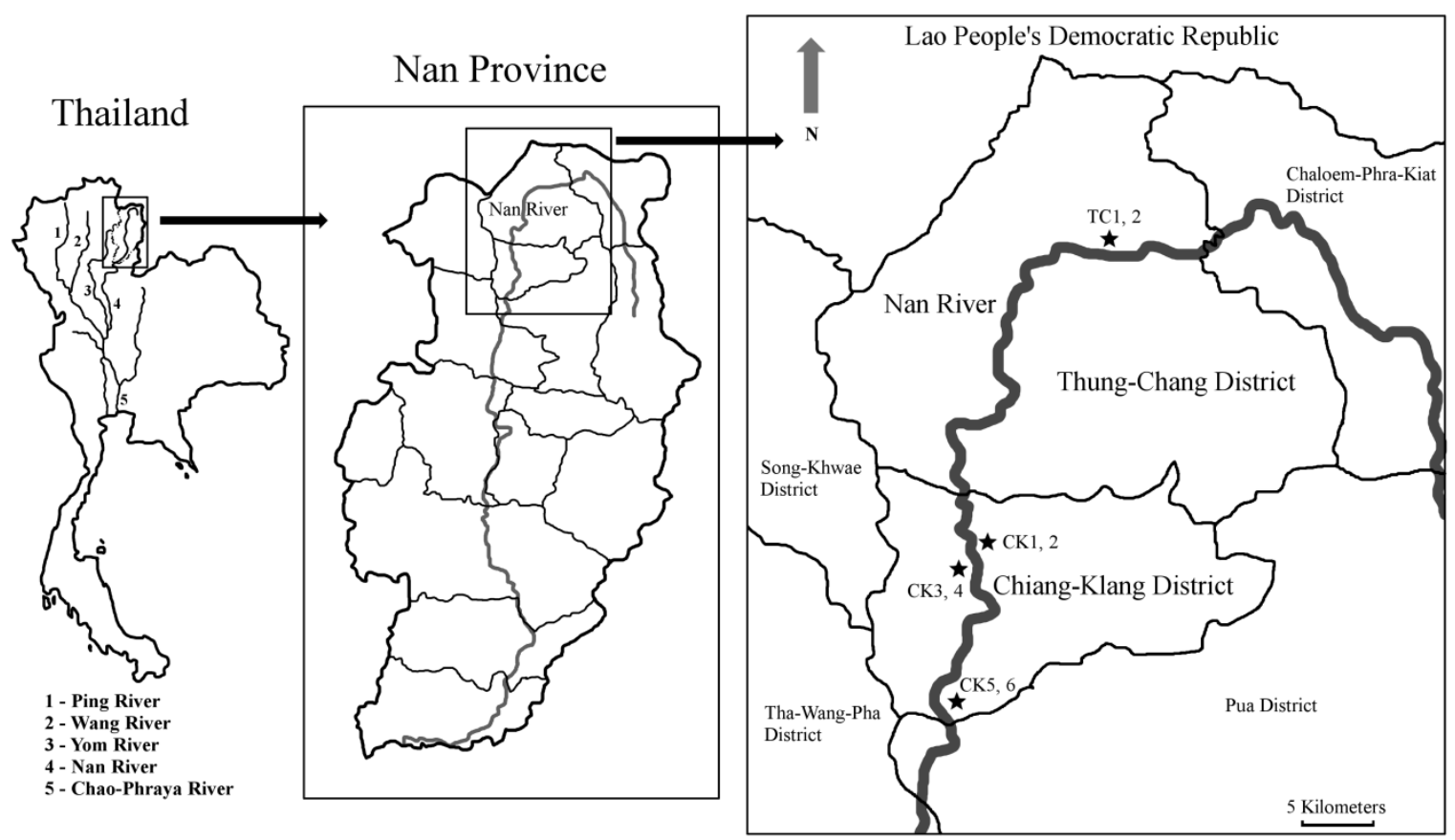

Figure 1. The location points of eight sampling sites along the Nan River in Chiang-Klang and Tung-Chang Districts, Nan Province.

Table 1. Location and detail of the eight sampling sites along Nan River.

\begin{tabular}{ccccc}
\hline $\begin{array}{c}\text { Site } \\
\text { No. }\end{array}$ & $\begin{array}{c}\text { Sampling } \\
\text { Site }\end{array}$ & $\begin{array}{c}\text { Latitude } \\
\left({ }^{\circ} \mathbf{N}\right)\end{array}$ & $\begin{array}{c}\text { Longitude } \\
\left({ }^{\circ} \mathbf{E}\right)\end{array}$ & $\begin{array}{c}\text { Altitude (meters } \\
\text { above sea level) }\end{array}$ \\
\hline 1 & TC1 & $19^{\circ} 30^{\prime} 58.78^{\prime \prime}$ & $100^{\circ} 56^{\prime} 3.47^{\prime \prime}$ & 374 \\
2 & TC2 & $19^{\circ} 30^{\prime} 59.67^{\prime \prime}$ & $100^{\circ} 55^{\prime} 57.06^{\prime \prime}$ & 371 \\
3 & CK1 & $19^{\circ} 19^{\prime} 1.99^{\prime \prime}$ & $100^{\circ} 50^{\prime} 43.87^{\prime \prime}$ & 259 \\
4 & CK2 & $19^{\circ} 18^{\prime} 50.58^{\prime \prime}$ & $100^{\circ} 50^{\prime} 51.93^{\prime \prime}$ & 258 \\
5 & CK3 & $19^{\circ} 18^{\prime} 22.10^{\prime \prime}$ & $100^{\circ} 50^{\prime} 58.51^{\prime \prime}$ & 257 \\
6 & CK4 & $19^{\circ} 18^{\prime} 16.85^{\prime \prime}$ & $100^{\circ} 50^{\prime} 55.41^{\prime \prime}$ & 256 \\
7 & CK5 & $19^{\circ} 13^{\prime} 31.60^{\prime \prime}$ & $100^{\circ} 49^{\prime} 29.69^{\prime \prime}$ & 252 \\
8 & CK6 & $19^{\circ} 13^{\prime} 31.08^{\prime \prime}$ & $100^{\circ} 49^{\prime} 28.52^{\prime \prime}$ & 246 \\
\hline
\end{tabular}




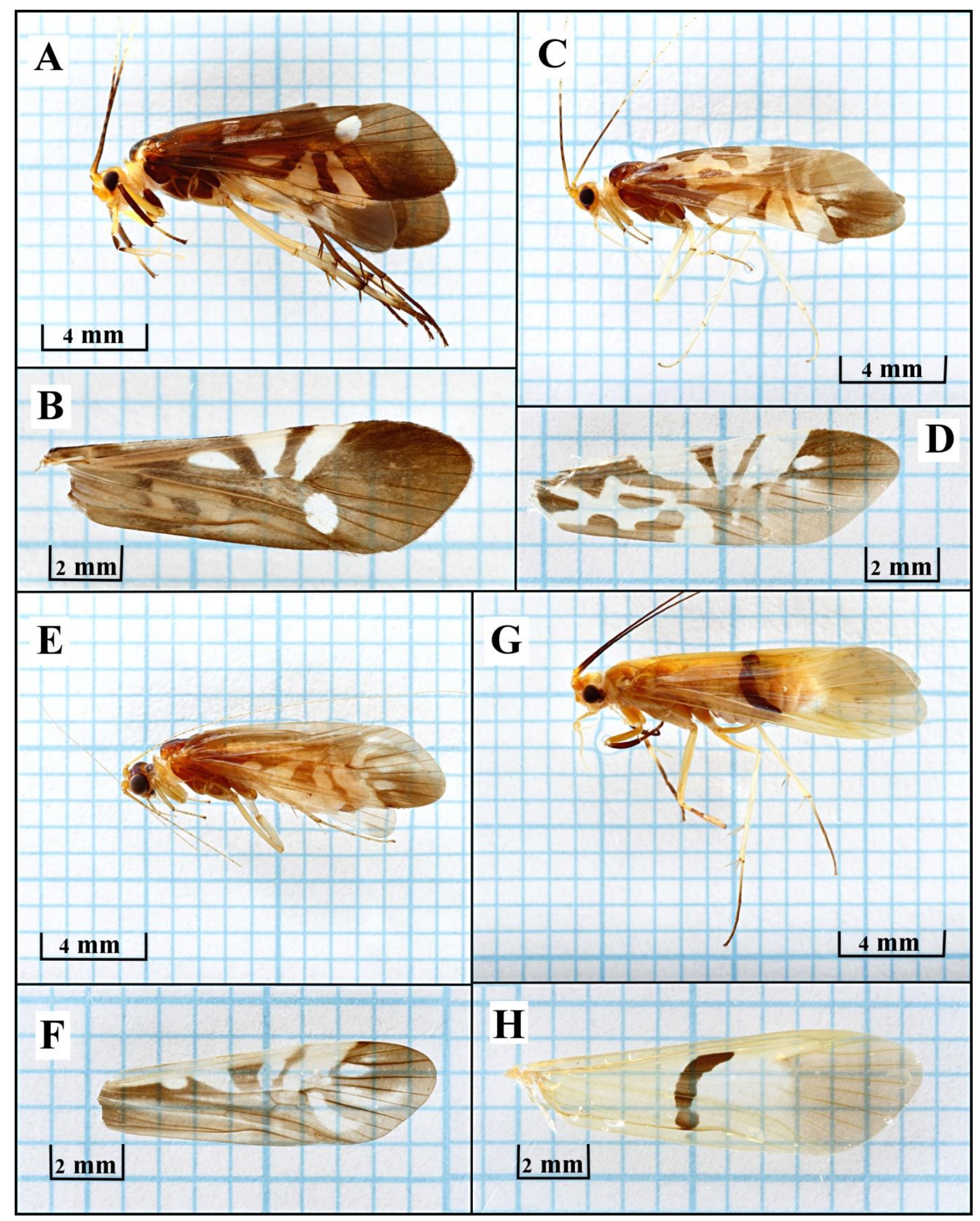

Figure 2. Adult of four Macrostemum species with left female forewings: M. dohrni (A, B), M. floridum (C, D), M. indistinctum (E, F), M. midas $(\mathrm{G}, \mathrm{H})$. 


\section{Environmental factor monitoring}

Environmental factors were monthly measured with grab sampling technique at the same time with insect collection. Thermometer was used for recording air and water temperature. Wet-dry thermometer was setup along the riverbank for relative humidity (\%RH) that was recorded two times: in the morning (6.00 AM, \%RH-M) and evening (6.00 PM, \%RH-E). Electrical conductivity (EC), $\mathrm{pH}$ and total dissolved solids (TDS) were measured by using multi-parameter analyzer (CONSORT Model C533). The nutrients (nitratenitrogen, ammonia and orthophosphate: Ortho-P) and turbidity were analyzed with absorbance method with Hach Model DR2000 Laboratory spectrophotometer. Azide modification Method was used to specify dissolved oxygen (DO) concentration and biological oxygen demand $\left(\mathrm{BOD}_{5}\right)$.

\section{Data analysis}

The environmental factor data were analyzed among the site location and seasonal studies by using One-way ANOVA. The male and female abundance of four species were reported in eight sampling sites during 12-months studies. The relationships between emerging male and female populations were analyzed by a linear regression. The influences of environmental factors on the population of male and female of 4 species of Macrostemum were analyzed by using a multivariate general linear model (Ellsworth, 2000) and the significant effects were considering by a linear regression analysis. All analysis methods were processed in PAST (Paleontological Statistic) version 3.19.

\section{RESULTS}

Total of 1,092 specimens were collected from eight sampling sites for a year. Female was massively abundant and had higher number than male. The most abundant specie was $M$. floridum (936 individuals) following by $M$. midas (97 individuals). M. dohrni and $M$. indistinctum were found 48 and 11 individuals, respectively. Three species ( $M$. floridum, $M$. indistinctum and $M$. midas) had higher female abundance than male, whereas the equal sex ratio of $M$. dohrni was showed.

The female and male numbers of M. dohrni, M. floridum and M. midas showed strongly positive relationship, whereas there was none significance in male and female of M. indistinctum (Table 2). 
Table 2. Correlation coefficient(r) from linear regression analysis among male and female of Hydropsychidae species in genus Macrostemum from Nan River.

\begin{tabular}{lcccc}
\hline \multirow{2}{*}{ Male } & \multicolumn{4}{c}{ Female } \\
\cline { 2 - 5 } & M. dohrni & M. floridum & M. indistinctum & M. midas \\
\hline M. dohrni $(\mathrm{n}=10)$ & $0.67^{*}$ & - & - & - \\
M. floridum $(\mathrm{n}=53)$ & - & $0.85^{*}$ & - & - \\
M. indistinctum $(\mathrm{n}=7)$ & - & - & -0.55 & - \\
M. midas $(\mathrm{n}=19)$ & - & - & - & $0.83^{*}$ \\
\hline Note: $\mathrm{n}=$ amount of data set, * indicated $\mathrm{p}$ value was significant at $<0.05$. &
\end{tabular}

\section{Distribution along Nan River}

The upstream reaches (TC sites) had lower proportion of caddisfly abundance than lower reaches (CK sites) (Figure 3). M. floridum was the most common specie in the study and found at all sampling sites, especially in lower reaches. M. indistinctum was only found in lower reaches (CK sites). On the contrary, the abundance of $M$. dohrni and M. midas at the upstream reaches were higher than at CK sites.

\section{Occurrence period}

Flight periodicity of Macrostemum caddisfly was monthly different (Figure 4). M. floridum had the longest flight period that almost all year round. Population of $M$. floridum tended to low in March and was almost absent in September when an only male appeared. Adult of M. midas and M. dohrni was found for 9 and 6 months, respectively, whereas the shortest flight period was showed by $M$. indistinctum. The weather of Northern Thailand can be separated into three seasons: cool season (mid-October to mid-February), hot season (midFebruary to mid-May) and rainy season (mid-May to mid-October), which $M$. dohrni and M. indistinctum were not found in the early of rainy season. During hot season, the population peak of M. dohrni and M. midas occurred in April, whereas $M$. floridum peaked in March. On the contrary, $M$. indistinctum had the population peak in cool season (November). 


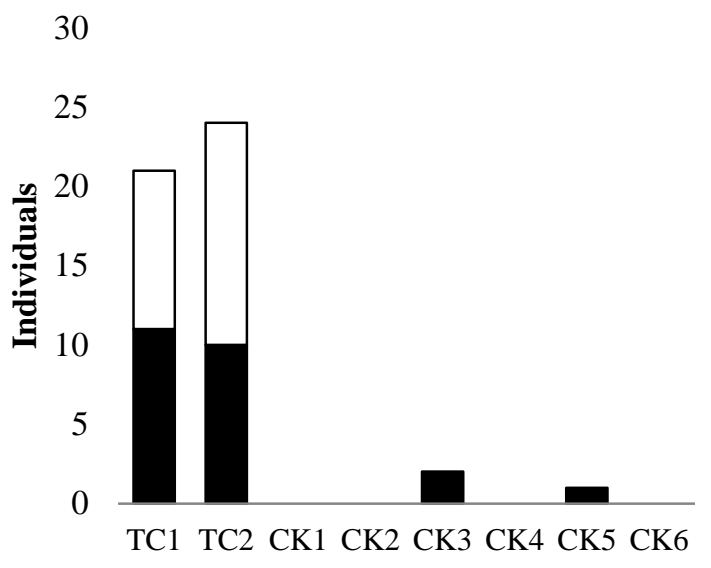

-M.dohrni-Male aM.dohrni-Female

$$
5
$$

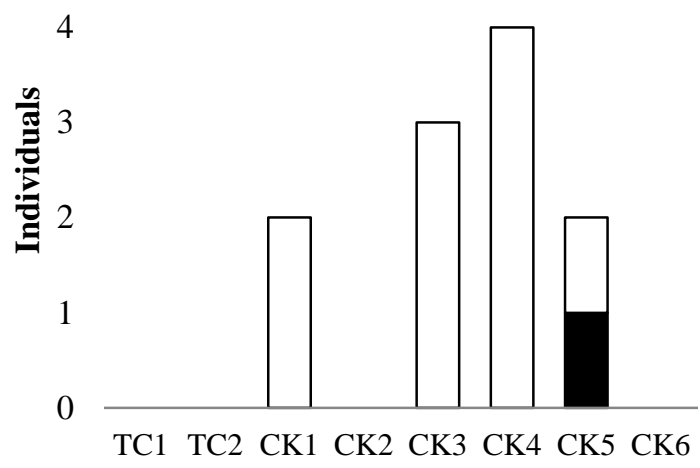

-M.indistinctum-Male $\square$ M.indistinctum-Female

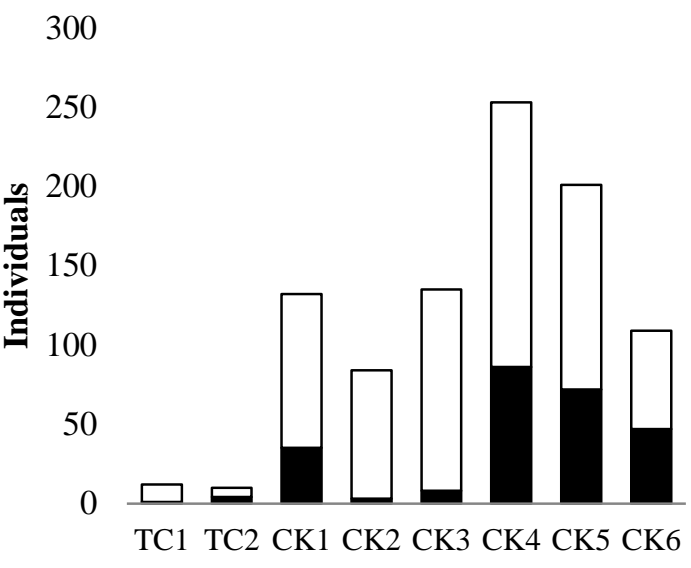

-M.floridum-Male $\square$ M.floridum-Female

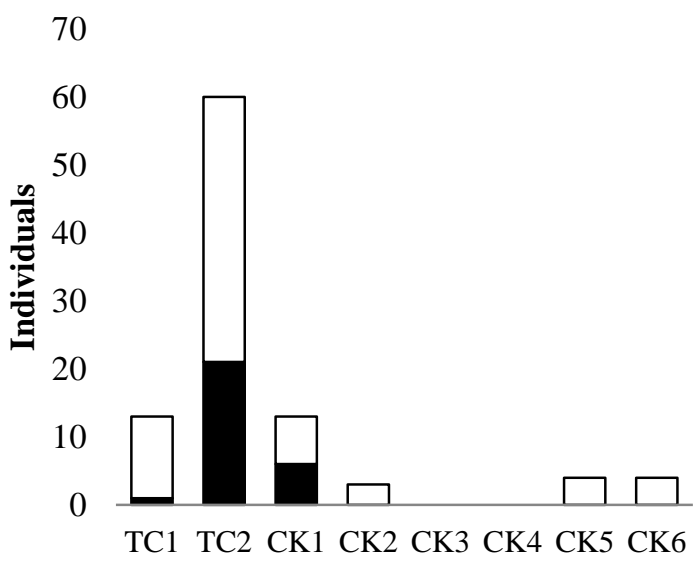

-M.midas-Male $\square$ M.midas-Female

Figure 3. Abundance of adult caddisflies (Macrostemum spp.) at eight sampling sites along Nan River. 

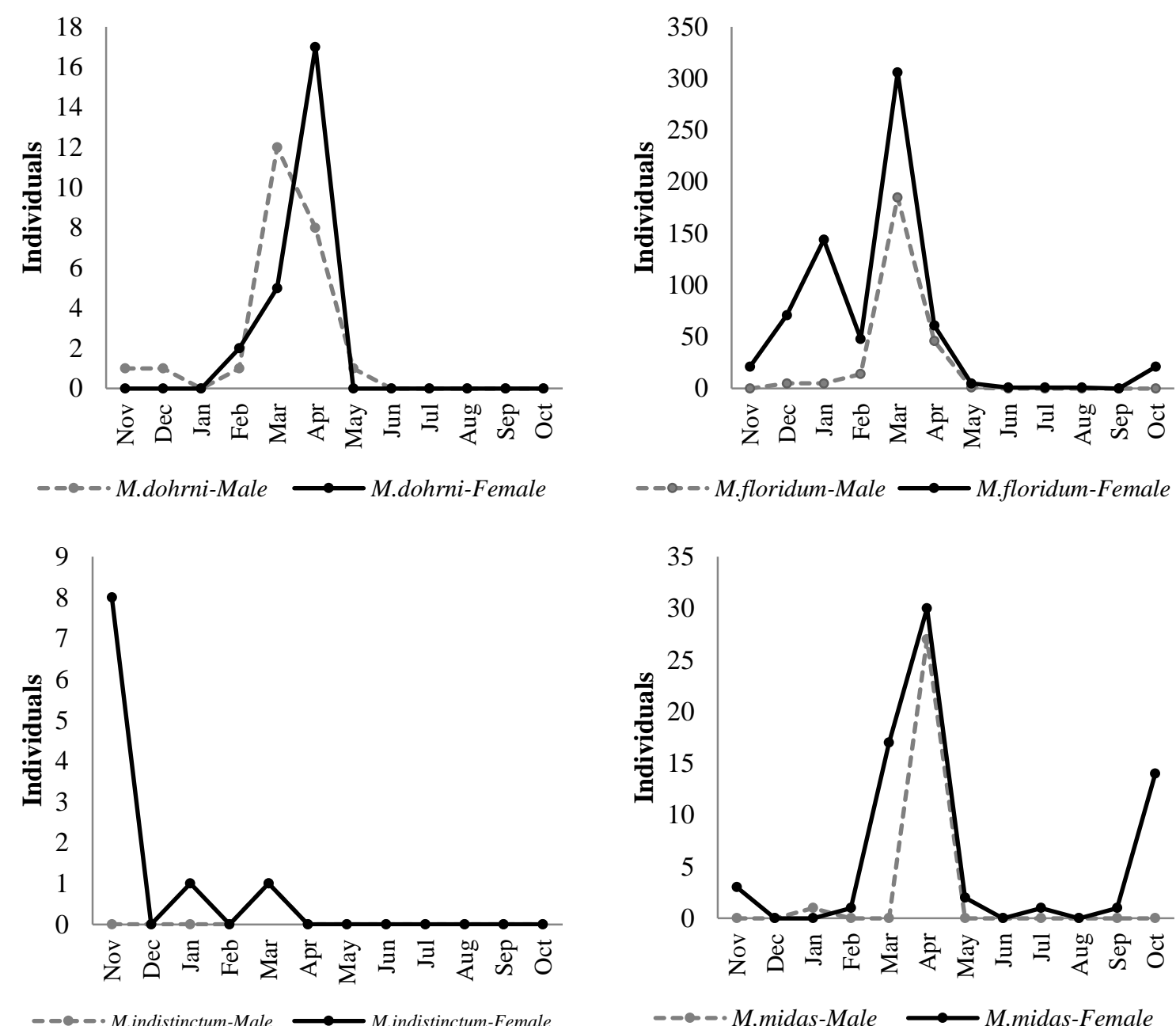

Figure 4. Number of individual of four adult caddisfly species in genus Macrostemum collected during 12-months study. 
Table 3. Mean and SD of environmental parameters of eight sampling sites in Nan River.

\begin{tabular}{|c|c|c|c|c|c|c|c|c|}
\hline \multirow{2}{*}{$\begin{array}{c}\text { Paramet } \\
\text { ers }\end{array}$} & \multicolumn{8}{|c|}{ Sampling sites } \\
\hline & TC1 & TC2 & CK1 & CK2 & CK3 & CK4 & CK5 & CK6 \\
\hline$\%$ RH-E & $70 \pm 14$ & $71 \pm 15$ & $71 \pm 14$ & $73 \pm 15$ & $72 \pm 14$ & $70 \pm 13$ & $78 \pm 7$ & $76 \pm 6$ \\
\hline$\%$ RH-M & $87 \pm 6$ & $90 \pm 5$ & $90 \pm 9$ & $92 \pm 7$ & $87 \pm 13$ & $86 \pm 14$ & $88 \pm 7$ & $88 \pm 8$ \\
\hline $\begin{array}{l}\text { AirT } \\
\left({ }^{\circ} \mathrm{C}\right)\end{array}$ & $28.8 \pm 3.9$ & $29.5 \pm 3.3$ & $29.7 \pm 3.7$ & $30.3 \pm 3.6$ & $30.1 \pm 3.9$ & $30.0 \pm 3.8$ & $28.1 \pm 5.2$ & $27.9 \pm 5.0$ \\
\hline $\begin{array}{l}\text { WaterT } \\
\left({ }^{\circ} \mathrm{C}\right)\end{array}$ & $24.3 \pm 3.5$ & $24.6 \pm 3.2$ & $25.5 \pm 2.4$ & $25.1 \pm 3.3$ & $26.4 \pm 2.9$ & $26.6 \pm 2.8$ & $25.1 \pm 2.4$ & $25.3 \pm 2.5$ \\
\hline $\mathrm{pH}^{*}$ & $8.11 \pm 0.39^{\text {cd }}$ & $8.19 \pm 0.29^{\mathrm{d}}$ & $7.95 \pm 0.43^{\mathrm{bcd}}$ & $7.96 \pm 0.51^{\mathrm{bcd}}$ & $7.76 \pm 0.46^{\mathrm{ab}}$ & $7.88 \pm 0.45^{\mathrm{bc}}$ & $7.57 \pm 0.35^{\mathrm{a}}$ & $7.72 \pm 0.36^{\mathrm{ab}}$ \\
\hline $\begin{array}{l}\mathrm{EC} \\
(\mu \mathrm{S} / \mathrm{cm})^{*}\end{array}$ & $275 \pm 52^{\mathrm{b}}$ & $270 \pm 49^{\mathrm{b}}$ & $260 \pm 57^{\mathrm{ab}}$ & $251 \pm 66^{\mathrm{ab}}$ & $262 \pm 35^{\mathrm{ab}}$ & $268 \pm 34^{b}$ & $232 \pm 34^{\mathrm{a}}$ & $235 \pm 31^{\mathrm{a}}$ \\
\hline $\begin{array}{l}\text { TDS } \\
(\mathrm{mg} / \mathrm{L}) *\end{array}$ & $147 \pm 28^{c}$ & $144 \pm 26^{c}$ & $138 \pm 31^{\mathrm{abc}}$ & $134 \pm 35^{\mathrm{abc}}$ & $141 \pm 18^{\mathrm{bc}}$ & $142 \pm 18^{c}$ & $124 \pm 18^{\mathrm{a}}$ & $124 \pm 16^{\mathrm{ab}}$ \\
\hline $\begin{array}{l}\text { Nitrate } \\
(\mathrm{mg} / \mathrm{L})\end{array}$ & $1.4 \pm 0.2$ & $1.3 \pm 0.3$ & $1.3 \pm 0.3$ & $1.2 \pm 0.4$ & $1.2 \pm 0.3$ & $1.2 \pm 0.3$ & $1.2 \pm 0.4$ & $1.2 \pm 0.3$ \\
\hline $\begin{array}{l}\text { Ammonia } \\
(\mathrm{mg} / \mathrm{L})\end{array}$ & $0.10 \pm 0.11$ & $0.14 \pm 0.16$ & $0.19 \pm 0.25$ & $0.17 \pm 0.12$ & $0.18 \pm 0.17$ & $0.20 \pm 0.21$ & $0.19 \pm 0.13$ & $0.19 \pm 0.13$ \\
\hline $\begin{array}{l}\text { Ortho-P } \\
\text { (mg/L) }\end{array}$ & $0.23 \pm 0.13$ & $0.22 \pm 0.11$ & $0.27 \pm 0.16$ & $0.24 \pm 0.14$ & $0.24 \pm 0.13$ & $0.24 \pm 0.12$ & $0.25 \pm 0.14$ & $0.24 \pm 0.14$ \\
\hline $\begin{array}{l}\text { Turbidity } \\
\text { (FTU) }\end{array}$ & $44 \pm 80$ & $42 \pm 77$ & $74 \pm 131$ & $73 \pm 130$ & $58 \pm 89$ & $61 \pm 97$ & $64 \pm 99$ & $67 \pm 104$ \\
\hline $\begin{array}{l}\mathrm{DO} \\
(\mathrm{mg} / \mathrm{L})\end{array}$ & $8.3 \pm 0.9$ & $8.4 \pm 0.9$ & $8.1 \pm 0.7$ & $8.0 \pm 0.8$ & $8.1 \pm 0.6$ & $8.2 \pm 0.6$ & $7.9 \pm 0.4$ & $7.7 \pm 0.5$ \\
\hline $\begin{array}{l}\mathrm{BOD}_{5} \\
(\mathrm{mg} / \mathrm{L})\end{array}$ & $0.6 \pm 0.5$ & $0.6 \pm 0.5$ & $0.7 \pm 0.6$ & $0.7 \pm 0.6$ & $0.7 \pm 0.4$ & $0.7 \pm 0.6$ & $0.8 \pm 0.6$ & $0.6 \pm 0.4$ \\
\hline
\end{tabular}

Note: \%RH-E, Relative Humidity-Evening; \%RH-M, Relative Humidity-Morning; AirT, Air Temperature; WaterT, Water Temperature; EC, Electrical Conductivity; TDS, Total Dissolved Solids; DO, Dissolved Oxygen; BOD5, Biochemical Oxygen Demand.

* Significant level: $P<0.05$

Electrical conductivity, total dissolved solid and $\mathrm{pH}$ at eight sampling sites were significantly different $(P<0.05$; Table 3$)$, which TC sites had higher values than CK sites. The other factors, such as \% RH in morning and evening, air temperature, water temperature, nitrate, ammonia, orthophosphate, turbidity, dissolved oxygen and biochemical oxygen demand, were similar throughout eight sampling sites.

Seasonal environmental factors showed significant difference (Table 4). Relative humidity was lowest in hot season and highest in rainy season, whereas medium range occurred in cool season. Air and water temperature were highest in hot season and lowest in cool season. The $\mathrm{pH}$ values throughout the study period were in the range of 7.59-8.26 as common natural rivers. EC and TDS did 
not exceed $300 \mu \mathrm{S} / \mathrm{cm}$ and $160 \mathrm{mg} / \mathrm{L}$, respectively. Nitrate, ammonia and orthophosphate values in all seasons were not higher than $2.0,1.0$ and $0.7 \mathrm{mg} / \mathrm{L}$, respectively. The water depth increased up to $3 \mathrm{~m}$ during flooding periods.

Table 4. Significant seasonal difference of environmental parameters $(P<0.05)$.

\begin{tabular}{lccc}
\hline \multicolumn{1}{c}{ Parameters } & Cool season & Hot season & Rainy season \\
\hline$\%$ RH-E $(\mathrm{n}=96)$ & $74 \pm 9^{\mathrm{b}}$ & $61 \pm 12^{\mathrm{a}}$ & $79 \pm 10^{\mathrm{b}}$ \\
$\%$ RH-M $(\mathrm{n}=96)$ & $89 \pm 9^{\mathrm{ab}}$ & $84 \pm 12^{\mathrm{a}}$ & $91 \pm 6^{\mathrm{b}}$ \\
Air Temperature $\left({ }^{\circ} \mathrm{C}, \mathrm{n}=96\right)$ & $26.8 \pm 4.7^{\mathrm{a}}$ & $32.3 \pm 1.8^{\mathrm{c}}$ & $29.5 \pm 3.2^{\mathrm{b}}$ \\
Water Temperature $\left({ }^{\circ} \mathrm{C}, \mathrm{n}=96\right)$ & $23.0 \pm 2.6^{\mathrm{a}}$ & $26.9 \pm 2.5^{\mathrm{b}}$ & $26.3 \pm 2.1^{\mathrm{b}}$ \\
pH $(\mathrm{n}=288)$ & $7.99 \pm 0.42^{\mathrm{b}}$ & $8.26 \pm 0.23^{\mathrm{c}}$ & $7.59 \pm 0.33^{\mathrm{a}}$ \\
EC $(\mu \mathrm{S} / \mathrm{cm}, \mathrm{n}=288)$ & $258 \pm 23^{\mathrm{b}}$ & $292 \pm 25^{\mathrm{c}}$ & $234 \pm 57^{\mathrm{a}}$ \\
TDS $(\mathrm{mg} / \mathrm{L}, \mathrm{n}=288)$ & $138 \pm 12^{\mathrm{b}}$ & $155 \pm 14^{\mathrm{c}}$ & $124 \pm 30^{\mathrm{a}}$ \\
Nitrate $(\mathrm{mg} / \mathrm{L}, \mathrm{n}=288)$ & $1.1 \pm 0.4^{\mathrm{a}}$ & $1.3 \pm 0.2^{\mathrm{b}}$ & $1.4 \pm 0.3^{\mathrm{c}}$ \\
Ammonia $(\mathrm{mg} / \mathrm{L}, \mathrm{n}=288)$ & $0.14 \pm 0.13^{\mathrm{b}}$ & $0.10 \pm 0.08^{\mathrm{a}}$ & $0.24 \pm 0.20^{\mathrm{c}}$ \\
Ortho-P $(\mathrm{mg} / \mathrm{L}, \mathrm{n}=288)$ & $0.34 \pm 0.18^{\mathrm{b}}$ & $0.17 \pm 0.07^{\mathrm{a}}$ & $0.20 \pm 0.07^{\mathrm{a}}$ \\
Turbidity $(\mathrm{FTU}, \mathrm{n}=288)$ & $14 \pm 20^{\mathrm{a}}$ & $11 \pm 4^{\mathrm{a}}$ & $127 \pm 125^{\mathrm{b}}$ \\
DO $(\mathrm{mg} / \mathrm{L}, \mathrm{n}=96)$ & $8.6 \pm 0.6^{\mathrm{b}}$ & $7.8 \pm 0.6^{\mathrm{a}}$ & $7.9 \pm 0.6^{\mathrm{a}}$ \\
BOD $(\mathrm{mg} / \mathrm{L}, \mathrm{n}=96)$ & $0.9 \pm 0.6^{\mathrm{b}}$ & $0.5 \pm 0.3^{\mathrm{a}}$ & $0.6 \pm 0.5^{\mathrm{a}}$ \\
\hline
\end{tabular}

Note: \%RH-E, Relative Humidity-Evening; \%RH-M, Relative Humidity-Morning; EC, Electrical Conductivity; TDS, Total Dissolved Solids; DO, Dissolved Oxygen; BOD5, Biochemical Oxygen Demand.

A multivariate general linear model analysis with all environmental factors on the population of caddisflies (exceptional $M$. indistinctum male) from 8 sampling sites during 12-months study revealed 6 significant relationships (Table 5 and Figure 5). Four factors had the influence on 3 species (M. floridum, $M$. indistinctum and $M$. midas). The relative air humidity in evening and morning related significantly in negative effects with both male and female of $M$. floridum and $M$. midas female. M. indistinctum female and $\mathrm{pH}$ had a significant negative relationship, whereas $\mathrm{BOD}_{5}$ related positively to their population. Air and water temperature, EC, TDS, nitrate, ammonia, orthophosphate, turbidity and DO did not have any significant influences on these caddisfly in Nan River. Furthermore, both male and female of $M$. dohrni and M. midas male was not found any relationship with all measured environmental factors in this study. 
Table 5. Correlation coefficient(r) from linear regression analysis with Hydropsychidae species in genus Macrostemum (Macrostemum dohrni(M.d)/M. floridum(M.f)/M indistinctum (M.i)/M. midas(M.m) and environmental factors in Nan River.

\begin{tabular}{|c|c|c|c|c|c|c|c|c|c|c|c|c|c|}
\hline Taxon & 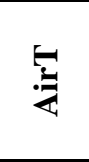 & 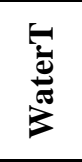 & $\frac{\pi}{2}$ & ن & $\tilde{\theta}$ & 䔍 & 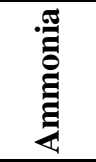 & 产 & 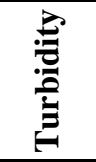 & ஜ & Оิ & $\begin{array}{l}\frac{15}{1} \\
\frac{1}{2} \\
0\end{array}$ & $\begin{array}{l}\sum_{1} \\
\frac{1}{2} \\
\frac{\pi}{0}\end{array}$ \\
\hline M.d-male $(\mathrm{n}=10)$ & 0.37 & 0.28 & 0.36 & 0.01 & -0.05 & 0.40 & 0.19 & 0.10 & -0.17 & -0.51 & -0.03 & -0.57 & -0.11 \\
\hline$M . d$-female $(\mathrm{n}=5)$ & 0.61 & 0.85 & 0.14 & 0.70 & 0.70 & 0.31 & 0.82 & 0.59 & 0.80 & -0.10 & -0.61 & -0.77 & 0.60 \\
\hline$M . f$-male $(\mathrm{n}=24)$ & 0.24 & 0.17 & -0.07 & 0.07 & 0.07 & 0.17 & -0.05 & -0.22 & 0.03 & 0.04 & -0.16 & -0.18 & $-0.53 *$ \\
\hline$M . f$-female $(\mathrm{n}=51)$ & 0.17 & 0.06 & 0.07 & 0.12 & 0.13 & -0.02 & -0.21 & 0.01 & -0.16 & 0.11 & -0.25 & $-0.29 *$ & $-0.39^{*}$ \\
\hline M. $i$-male $(\mathrm{n}=1)$ & - & - & - & - & - & - & - & - & - & - & - & - & 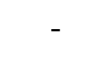 \\
\hline$M . i$-female $(\mathrm{n}=6)$ & 0.38 & 0.32 & $-0.96^{*}$ & 0.05 & 0.01 & -0.53 & 0.28 & -0.68 & 0.21 & 0.31 & $0.93^{*}$ & 0.39 & 0.20 \\
\hline M.m-male $(\mathrm{n}=4)$ & 0.45 & 0.42 & 0.28 & 0.35 & 0.34 & 0.18 & 0.29 & -0.21 & 0.26 & -0.45 & 0.63 & -0.40 & 0.45 \\
\hline M.m-female $(\mathrm{n}=18)$ & 0.29 & 0.41 & 0.42 & 0.46 & 0.46 & 0.05 & -0.30 & 0.01 & -0.20 & -0.45 & -0.11 & $-0.47 *$ & 0.02 \\
\hline
\end{tabular}

Note: $\mathrm{n}=$ amount of data set, $*$ indicated $P$ value was significant at $<0.05$.

\section{DISSCUSSION}

Thailand found 12 caddisfly species in genus Macrostemum that also distribute in the other countries, such as Cambodia, Laos, Penninsular Malaysia, Sumatra, Vietnam and Myanmar (Hoang et al., 2005; Malicky, 2010; Wityi et al., 2015). Nan River was recorded for four species that were initially captured by this study. M. floridum and M. midas were also found in Northern and Western Thailand along Ping River, some streams and national parks (Chaibu et al., 2002; Thapanya et al., 2004; Prommi, 2015), whereas M. indistinctum and M. dohrni were found in western and southern areas, such as Mae-Klong Watershed and Ko Hong Hill (Prommi and Permkamm, 2010; Prommi, 2015).

The relationship of caddisfly genders, in case of female population decrease, male will have similar trend. The result could be applied to tracking the caddisfly population for further conservation plan. 

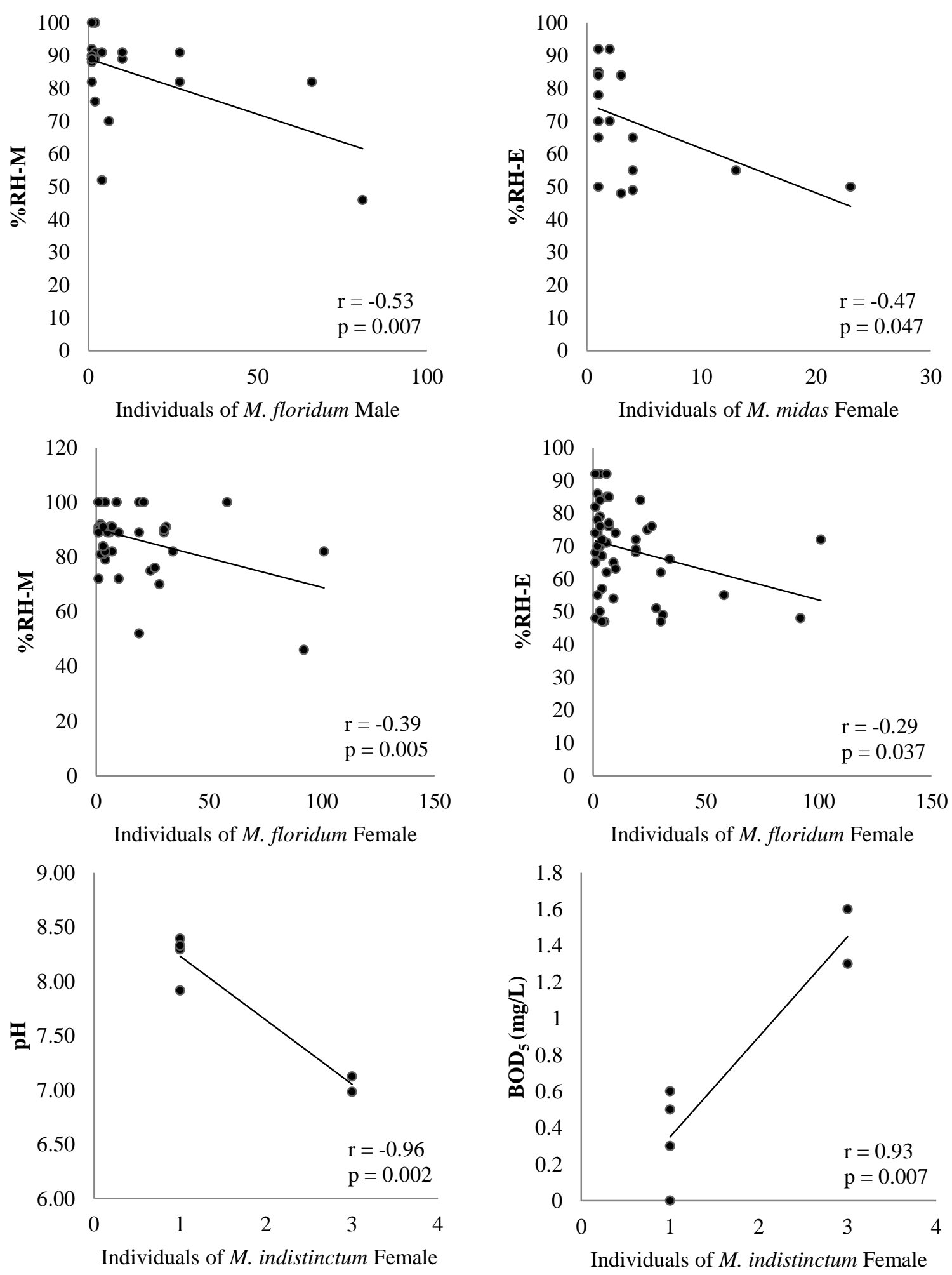

Figure 5. Relationship between individual of three adult caddisfly species ( $M$. floridum, $M$. indistinctum and $M$. midas) and four environmental factors (\%RH-E, \% RH-M, $\mathrm{pH}$ and $\left.\mathrm{BOD}_{5}\right)$. 
This study showed that downstream reaches (CK1-CK6) had more suitable habitat for M. floridum and $M$. indistinctum. The riverbanks of downstream reaches were the open area and agricultural farm which were preferred for these species. In contrast, TC sites with the high abundance of M. dohrni and M. midas were surrounded by natural forest with low human disturbance. The previous study in National Park in Northern Thailand mentioned the distribution of $M$. midas at the altitude of 400-600 m (Thapanya et al., 2004) that was close to the altitude of TC sites. In addition, M. dohrni in Vietnam was also found in preserved streams (Hoang et al., 2005). The result supported that the characteristic of riverbanks affected on the environmental condition along the river and might be cause of the distribution patterns in different species. $M$. indistinctum was a rare species for the study because the collected specimens did not exceed 4 individuals each site each month throughout the sampling period and the only one male was caught. However, the flight period of $M$. indistinctum might occur in the different period of light trap operation that caused few trapped specimens.

The rainy season showed the lowest caddisfly population because high air humidity had high negative influence on flight activity of caddisflies, while as the highest occurred in lowest humidity during hot season. M. indistinctum occurred in low temperature which conforming to the study in Ko Hong Hill, southern Thailand that indicated the peak in January (Prommi and Permkamm, 2010). The peaks of four caddisfly species could be explained that $M$. dohrni, M. floridum and $M$. indistinctum were univoltine, except $M$. midas that had another peak in October. Therefore, this study could be not confirmed that M. midas was univoltine or bivoltine. However, the previous study in Mae-Klong Watershed noted that $M$. midas was not found during low water and air temperature (Prommi, 2015) that was similar to cool season in this study. Furthermore, late emergence of some Macrostemum species also occurred in Oregon where the altitude could affect larval development and made a bimodal flight period of some Hydropsychidae species (Anderson, 1976).

The highest values of EC and TDS were detected in hot season because of water-level decrease and high concentration of electrical conductors. On the contrary, the EC and TDS values in rainy season were diluted by massive rainfall. The highest values of turbidity were detected in rainy season because of sediment flushing from riverbank, whereas the water was clear and shallow during cool and hot seasons.

The relationship between adult caddisfly and environmental factors, female abundance had a respond on the effects from more several environmental factors than male. The lower numbers of caught male caddisflies than female were unsuitable for using their data for analysis the relationship with environmental factors. Therefore, a using adult caddisfly as bioindicator was recommended the gathering of many caddisfly to monitoring the environmental 
status of caddisfly's habitat. However, most sensitive species in this study were M. floridum, because male and female had the significant relationship with relative air humidity. The high humidity condition was unsuitable for insect flight activity with lower number of caught specimen. Previous study in Southern Thailand, $M$. indistinctum female was also a rare species like this study, but none of significant relationship with aquatic environmental factor was reported (Prommi and Permkam, 2010). In this study, this species had the significant relationships with $\mathrm{pH}$ and $\mathrm{BOD}_{5}$ but their population data was extremely low. Therefore, this species was not suitable to be a bioindicator to any factors, but they should be recognized as a rare species for conservation. This result indicated that various environmental factors in nature had the effects on genus Macrostemum caddisfly abundance in Nan River. According to water quality data of Nan River, the seasonal fluctuation on river conditions was the possible main influence on the occurrence of adult caddisfly and the different habitat condition by surrounded environment affected to the caddisfly distribution in this river.

\section{CONCLUSIONS}

This study helped to update the information on distribution and annual occurrence pattern of four caddisflies species (genus Macrostemum) in Thailand. The data on water quality at all sampling sites was useful to initially indicate that Nan River in Chiang-Klang and Tung-Chang Districts was still a good natural resource and low disturbed area for conservation of rare species like $M$. indistinctum. The environmental fluctuation related to seasonal change and affected some caddisflies by altering habitat conditions. The population dynamic of some caddisflies conformed to some aquatic and terrestrial environmental factors, which it was the useful information for developing to using adult caddisfly as bioindicator for environmental monitoring in Thailand.

\section{ACKNOWLEDGEMENTS}

Financial support by a Science Achievement Scholarship of Thailand (SAST) and the Aquatic Insect Research Unit in Department of Biology, Faculty of Science, Chiang Mai University is acknowledged.

\section{REFERENCES}

Anderson, N.H. 1976. The distribution and biology of the Oregon Trichoptera. Technical Bulletin 134. Corvallis (OR): Agricultural Experiment Station, Oregon State University. 
Badcock, R.M. 1976. The distribution of the Hydropsychidae in Great Britain. In: Malicky, H., editor. Proceedings of the First International Symposium on Trichoptera. Dordrecht: Springer. https://doi.org/10.1007/978-94-0101579-0_10

Bunlue, P., Chantaramongkol, P., Thapanya, D., and Malicky, H. 2012. The biodiversity of Trichoptera assemblage in Doi Suthep-Pui and Doi Inthanon National Parks, Chiang Mai, Thailand. Braueria. 39: 7-21.

Chaibu, P., Chantaramongkol, P., and Malicky, H. 2002. The caddisflies (Trichoptera) of the River Ping, northern Thailand, with particular reference to domestic pollution (Studies on Trichoptera in Thailand. Nr. 31). In: Mey W., editor. Proceedings of the $10^{\text {th }}$ International Symposium on Trichoptera, Nova Supplementa Entomologica, Keltern. 15: 331-342.

Coiller, K.J., and Smith, B.J. 1995. Sticky trapping of adult mayflies, stoneflies and caddisflies alongside three contrasting streams near Hamilton, New Zealand. New Zealand Natural Sciences. 22: 1-9.

De Moor, F.C., and Ivanov, V.D. 2008. Global diversity of caddisflies (Trichoptera: Insecta) in freshwater. Hydrobiologia. 595: 393-407.

Ellsworth, S.D. 2000. Influence of substrate size, Cladophora, and caddisfly pupal cases on colonization of macroinvertebrates in Sagehen Creek, California. Western North American Naturalist. 60:311-319.

Gordon, A.E., and Wallace, J.B. 1975. Distribution of the family Hydropsychidae (Trichoptera) in the Savannah River Basin of North Carolina, South Carolina, and Georgia. Hydrobiologia. 46(4): 405-423. https://doi.org/ 10.1007/BF00028283

Hoang, D.H., Tanida, K., and Bae, Y.J. 2005. Records of the Vietnamese Macronematinae (Hydropsychidae, Trichoptera) with description of a new species. Proceedings of the $11^{\text {th }}$ International Symposium on Trichoptera. Kanagawa: Tokai University Press. p.161-174.

Malicky, H. 2010. Atlas of Southeast Asian Trichoptera. Biology Department, Faculty of Science, Chiang Mai University, Chiang Mai.

Morse, J.C. 2011. The Trichoptera world checklist. Zoosymposia. 5: 372-380.

Nijboer, R. 2004. The ecological requirements of Agapetus fuscipes CURTIS (Glossosomatidae), a characteristic species in unimpacted streams. Limnologica. 34(3): 213-223. https://doi.org/10.1016/S0075-9511(04)800 $46-\mathrm{X}$

Prommi, T. 2015. Trichoptera fauna as stream monitoring of the Mae Klong watershed, Western Thailand. Advances in Environmental Biology. 9(26): $1-6$.

Prommi, T. 2016. Descriptions of larvae of four species of Hydropsyche (Hydropsychidae: Trichoptera) from Thailand. Zootaxa. 4158(4): 577591. https://doi.org/doi.org/10.11646/zootaxa.4158.4.9 
Prommi, T., Laudee, P., and Chareonviriyaphap, T. 2014. Biodiversity of adult Trichoptera and water quality variables in streams, northern Thailand. APCBEE Procedia. 10: 292-298. https://doi.org/10.1016/j.apcbee.2014. 10.055

Prommi, T., and Permkam, S. 2010. The caddisfly (Insect, Trichoptera) of Ko Hong Hill nature preserve, Southern Thailand. Denisia. 29: 295-302.

Promwong, W., and Thapanya, D. 2019. Monthly diversity and abundance of caddisflies in upstream and downstream areas of the Mae Ngat Somboonchol Dam, Chiang Mai Province, Thailand. Zoosymposia.14: 6880.

Pollution Control Department (PCD). 2003. State of water pollution Thailand 2003. Bangkok: PCD.

Ríos-Touma, B., Holzenthal, R.W., Huisman, J., Thomson, R., and RázuriGonzales, E. 2017. Diversity and distribution of the Caddisflies (Insecta Trichoptera) of Ecuador. Peer J. 5: e2851. https://doi.org/10.7717/ peerj.2851

Shafie, M.S.I., Wong, A.B.H., Harun, S., and Fikri, A.H., 2017. Land use influence on the aquatic insect communities on tropical forest streams of Liwagu River, Sabah, Malaysia. AACL Bioflux. 10(2): 341-352.

Suhaila, A.H., and Che Salmah, M.R. 2017. Ephemeroptera, plecoptera and trichoptera (insecta) abundance, diversity and role in leaf litter breakdown in tropical Headwater River. Tropical Life Sciences Research. 28(2): 89105. https://doi.org/10.21315/tlsr2017.28.2.7

Thapanya, D., Chantaramongkol, P., and Malicky, H. 2004. An updated survey of caddisflies (Trichoptera, Insecta) from Doi Suthep-Pui and Doi Inthanon National Parks, Chiang Mai Province, Thailand. The Natural History Journal of Chulalongkorn University. 4(1): 21-40.

Wiggins, G.B. 1996. Larvae of the North American caddisfly genera. $2^{\text {nd }}$ edition. Toronto: University of Toronto Press.

Wityi, H., Nozaki, T., and Fujino, T., 2015. A list of Myanmar caddisflies (Trichoptera) including recently collected data. Entomological Reserach Bulletin. 31 (special issue: Bae Y.J., editor. Proceedings of $2^{\text {nd }}$ BSA Symposium): 41-55. 